\title{
PLATE TECTONICS AND TECTONIC MAPPING
}

by

\section{J. Duncan Keppie}

A tectonic map attempts to portray the origin and evolution, in space and time, of a region. While plate tectonic concepts have been successfully applied to the Phanerozoic and Proterozoic, their application to the Archean is still under debate. The advent of plate tectonic theory heralds a new generation of tectonic maps for most of the Earth's surface, namely that part underlain by Phanerozoic and Proterozoic rocks. It may be necessary, however, to base tectonic mapping of Archean terrains upon an alternative tectonic model.

\section{Introduction}

In tectonic mapping of the Province of Nova Scotia, Canada, using plate tectonic theory, three hierarchical categories of rocks have been recognized: zones, stages and elements (Keppie, 1979; in press).

A tectonic zone is characterized by the nature of the underlying crust (continental, transitional or oceanic) at the time the rocks were formed and is closed in time by an orogeny. An exception is the present phase of tectonic evolution which is incomplete. A tectonic stage is a phase of tectonic development forming part of a tectonic zone and is characterized by an association of tectonic elements. The following stages are recognized: stable, rift, atlantic, pacific and transpression. These terms are not capitalized so as to avoid confusion with present day processes in the Atlantic and Pacific regions, for example.

A tectonic element is a certain, specific, well-defined tectonic environment, characterized by a distinct tectono-stratigraphic or tectono-plutonic rock unit that is part of a tectonic zone or stage. Examples of tectonic elements are continental shelf, forearc basin, marginal basin and magmatic arc. These tectonic units may exist side by side at any point in time, and conversely any area may belong to several different tectonic units as it evolves through time.

The scale of a tectonic map controls the degree of subdivision shown. Thus, on small-scale maps only tectonic zones may be shown, intermediate-scale maps may include tectonic zones, stages and possibly combinations of elements, and large-scale maps can portray all three categories. Structural elements, including fold traces, foliations and faults, can also be plotted on a tectonic map as can structural contours in undeformed or mildly deformed basins and the axes of gravity and magnetic anomalies.

\section{Tectonics and Structural Geology}

Before embarking on a discussion of tectonic mapping, it is essential to clarify the terms "tectonics" and "structural geology". Although structural geology is adequately defined in texts and geological dictionaries, the definition of tectonics ranges from being synonymous with structural geology (e.g. Schieferdecker, 1959) to statements that tectonics is an independent branch of geology (e.g. Bates and Jackson, 1980). The definitions preferred by this author are as follows:

Structural geology deals with the form, arrangement and internal structure of rocks, and especially with the description, representation and analysis of structures, chiefly on a moderate to large scale. It follows that a structural map depicts the age and orientation of structures such as folds, faults or foliations and is predominantly objective.

Tectonics is the study of the broad architecture of the outer part of the Earth, the regional assembling of structural features and tectonic units, and their mutual relations, origin, and historical evolution (Bates and Jackson, 1980). Thus, a tectonic map illustrates and interprets the evolution of the architecture of the Earth's crust in time. Tectonic mapping involves a degree of subjectivity which becomes more objective as the properties of individual tectonic units are better understood. Tectonic maps display tectonic units in their present locations and are considerably more objective than pre-Mesozoic palaeotectonic maps which involve palinspastic reconstructions based on relatively limited data.

Tectonic maps are currently available for most countries in the world, and a history of tectonic mapping can be found in King (1969) and Scheibner (1972). According to the above definitions, some of these so-called tectonic maps should be described as structural maps. The first genuine tectonic map was produced by Argand (1924); considerable progress has been achieved since then. Most of these tectonic maps, however, have been based on the outdated geosynclinal theory (Coney, 1970), including many of those produced since the advent of the plate tectonic theory nearly two decades ago.

Several recent maps based on plate tectonic theory are the Tectonic Map of Canada (Douglas, 1973), the Tectonic Map of New South Wales (Scheibner, 1974, 1976), the Tectonic Map of the Indonesian Region (Hamilton, 1978, 1979), and the Tectonic Lithofacies Map of the Appalachian Orogen (Williams, 1978). These maps show considerable variation in their legends, probably in large part due to the rapid evolution of plate tectonic theory. A more formal scheme, based on plate tectonic theory, has been devised for the Tectonic Map of Nova Scotia (Keppie, in press).

\section{Plate Tectonic Theory}

Plate tectonic theory was developed for the ocean basins, and its rules can be applied quantitatively only to the Mesozoic and Cenozoic history of oceanic plates for which such information on spreading velocities, first motion solutions, and orientations of transform faults is available (Le Pichon et al., 1973). Nevertheless, plate tectonic theory has been applied qualitatively to many continental areas around the world. Most of these models explain the geology of areas which were, or are, continental margins, that is, passive continental margins or consuming plate boundaries where orogens are formed.

Such models form the essential part of any tectonic map because, once an area is "cratonized", it may become covered by relatively simple platformal cover rocks. With the increase in the diversity and amount of geological data relating to Mesozoic/Cenozoic plate margins and older parts of the geological record, plate tectonic models become more objective. It should be stressed that data from all subdisciplines of solid-earth science are essential to an integrated model, which has been generated for orogens as old as the earliest Proterozoic (Hoffman, 1980). Cogent theoretical arguments have been put forward for plate tectonics in the Late Archean (Burke et al., 1976); however, a consensus has not been reached (Kerr, 1978). Burke and Dewey (1973) have proposed that the plate tectonic regime was preceded by a permobile phase characterized by rapid convective circulation in the mantle and a thin lithosphere. If this is the 
case, then a modified tectonic model is a necessary prerequisite for producing a tectonic map for most of the Archean.

\section{Principles of Tectonic Mapping}

A tectonic map portrays at least three types of information: tectonic units, structural units and elements, and the shape of basins. In order to arrive at the most objective tectonic interpretation of any unit, it is necessary to compile and analyze as complete a range of geological parameters as possible, including stratigraphy, paleontology, structure, volcanism, plutonism, metamorphism, geochronology, and geophysics. These parameters are initially compiled in correlation charts or time/space diagrams. This allows tectonostratigraphic units to be defined which, following deposition, are transformed by deformation and metamorphism.

Of the recent tectonic maps based upon plate tectonic theory, a variety of tectonic units are shown for stratified rocks such as oceanic crust, melange, outer-arc basin, foreland basin, platform cover, continental slope and rise, but, generally plutonic rocks are not classified tectonically. Only on the Tectonic Map of New South Wales (Scheibner, 1974, $1976)$ is there a systematic attempt to categorize these tectonic units into tectonic stages, provinces and realms. Unfortunately, little distinction is made between these higher ranking tectonic units.

In the present scheme, three hierarchical categories of tectonic units are recognized: zones, stages and elements (Fig. 1, Table 1). Tectonic mapping proceeds by first defining the tectonic elements, which are then grouped into higher ranking tectonic units, stages and zones.

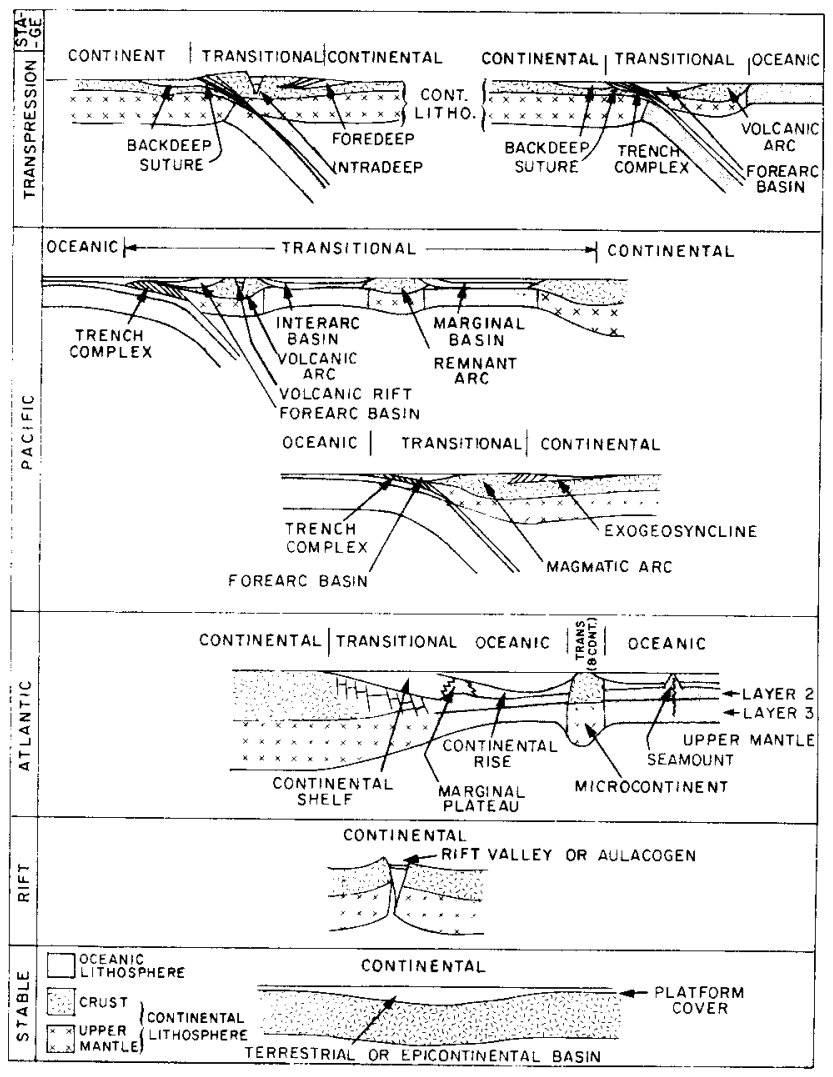

Figure 1: Tectonic zones, stages and elements. Note that tectonic stages can also co-exist in space at any one time.

\section{Tectonic Elements}

Tectonic elements are defined by their geological properties and may be grouped into the higher ranking tectonic units, stages and zones. Many names abound in the literature for tectonic elements and some that may be used in tectonic mapping are illustrated and tabulated with their properties (Fig. 1, Table 1). This list is open ended; others may be included as they become defined. Some of these tectonic elements require more precise definitions than current usage allows, but are not included here.

\section{Tectonic Stages}

Although a large number of stages in tectonic evolution have been recognized in modern plate tectonic settings (Burke and Whiteman, 1973; Dewey, 1969; Dewey and Horsfield, 1970; Keen, 1979; Dickinson, 1977), only the main stages can be clearly identified in ancient orogenic belts. Others may be classified as sub-stages. For example, if subduction of the mid-oceanic ridge can be recognized, it would be possible to separate out a mediterranean sub-stage of the pacific stage (Dewey, 1969). However, it is difficult at our present level of understanding to define unequivocal boundaries between sub-stages, and so they are not used in the present scheme.

The stable tectonic stage is represented by the cratonic cover deposits. The rift tectonic stage is characterized by aulacogens, half-grabens and rift valleys and the terrestrial deposits therein, and alkalic volcanism (Freund, 1965; Cherkunov, 1967; Illies, 1969; Burke and Whiteman, 1973). The boundary between the stable and rift stages is placed at the initiation of the bounding faults. These two stages occur in the continental and transitional tectonic zones.

The present spreading of the Atlantic Ocean is typical of the atlantic tectonic stage, and is characterized by continental shelf and rise and ocean floor deposits. The beginning of the atlantic stage is defined by the beginning of spreading, that is the appearance of new oceanic crust in an axial dyke accompanied by plateau basalts and dyke swarm feeders. This tectonic stage may occur in all three tectonic zones.

The pacific tectonic stage is typified by the present Pacific Ocean in which the mid-oceanic ridge, in places, has been subducted. It is characterized by island arc complexes and cordilleran-type continental margins (Dewey and Horsfield, 1970). The initiation of the pacific stage is defined by the start of subduction, that is the formation of Franciscan facies melanges followed by calcalkaline volcanicity. This tectonic stage may occur in all three tectonic zones.

The transpression tectonic stage is characterized by deposits of molasse in foredeeps, intradeeps and backdeeps, alkalictholeiitic volcanism, and ring complexes and calderas, which are usually deformed by transpression (folding and transcurrent faulting) but are rarely metamorphosed. During this stage the relative motion may vary from perpendicular, through oblique to parallel, and depending on the shape of the margin, ( $S$ or $Z)$ zones of compression or tension may form. The start of the transpression stage is defined by the time of suturing and the beginning of molasse deposition. This tectonic stage may also occur in all three tectonic zones.

Although the tectonic stages have been described in a sequence which might be considered an ideal tectonic cycle, no determining sequence of events can be assumed in plate tectonic theory because, for example, crustal separation can occur any time in any place (Coney, 1970). It should also be noted that the boundaries between tectonic stages are often diachronous.

\section{Tectonic Zone}

The oceanic tectonic zone (similar to oceanic realm and tectonic province of Scheibner, 1976) is characterized by 
TABLE 1

Classification and Characteristic Geological Properties of Tectonic Stages and Tectonic Elements



Note that no cycle of tectonic stages is implied because many lines of evolution can occur in plate tectonics. 
presence of oceanic lithosphere (oceanic crust and upper mantle). Its thickness and the depth of the ocean increases proportionately away from the mid-oceanic ridges according to its cooling rate and age (Rona, 1973). The average thickness of the oceanic lithosphere is $70 \mathrm{~km}$. The oceanic crust is generally made up of three layers: layer 1, pelagic and hemipelagic sediments up to about $500 \mathrm{~m}$ thick; layer 2, submarine abyssal tholeiitic basic flows 100-2000 m thick; and layer 3, greenschist facies metabasalts, amphibolites and gabbros about $5 \mathrm{~km}$ thick. Sheeted dyke complexes are typical of the boundary between layers 2 and 3 .

The continental tectonic zone (similar to the continental realm and epi-cratonic tectonic province of Scheibner, 1976) is characterized by cratonic covers on platforms overlying the continental lithosphere. The continental lithosphere, with an average thickness of $150-250 \mathrm{~km}$, is composed of continental crust $(~(35 \mathrm{~km})$ made up of an upper "granitic" crust and a lower "basaltic" crust of overlying upper mantle possibly composed of depleted residual peridotite (Ringwood, 1969).

The transitional tectonic zone (similar to the transitional realm, and pre-cratonic and transitional tectonic provinces of Scheibner, 1976) is characterized by rocks deposited where the nature of the underlying crust is transitional between continental and oceanic. Such transitions generally occur either on passive continental margins (e.g. Atlantic) or in active marginal mobile zones where unevenly distributed blocks of oceanic and continental crust of ten occur. Compared with the relatively simple geological record in oceanic and continental tectonic zones, the transitional zone has a varied and complex record typical of orogenic belts. Characteristic tectonic elements include rift, continental shelf and rise, calc-alkaline, "i"-type volcanic and magmatic arcs; intradeep and backdeep; and transpressional "s" and "is"- type plutonism (Chappell and White, 1974). These rocks exhibit a complete range of deformation and metamorphism.

These three tectonic zones can exist side by side and their geographic boundaries can be identified. The location of these boundaries only changes radically following orogenesis. Thus, tectonic zones are also bounded in time by orogenies.

The Glossary of Geology (Bates and Jackson, 1980) defines orogeny as the process by which structures within mountain areas were formed, including thrusting, folding and faulting in the outer and higher layers and plastic folding, metamorphism and plutonism in the inner and deeper layers. It usually occurs over a finite period of time, is fundamentally related to consuming plate margins and the accretion of terranes, and extends over a large area (Cebull, 1973). The end of an orogeny is used here to define the boundary between tectonic zones in time. A tectonic zone is named after the orogeny which terminates it. While it is recognized that orogenesis may die out gradually making the choice of a boundary somewhat arbitrary, experience has shown that a clear distinction generally can be made between molasse deposits and overlying cover rocks.

\section{Map Representation}

On the Tectonic Map of Nova Scotia, each tectonic stage is assigned one or more basic colours and each tectonic element bears a shade of colour dependent upon the stage to which it belongs. Structural elements, fold traces, foliations and faults are also included.

Fold traces and foliations are colour-coded according to the orogeny in which they formed. Faults are black with letters adjacent to the movement symbols to indicate the age of movement. Dykes are also plotted on the map because they indicate tensional stresses in the crust.

In undeformed or mildly deformed basins, structure contours preferably on its base or alternatively on some higher stratigraphic horizon are used to illustrate the shape of the basin. Axes of Bouguer gravity anomalies, both highs and lows, as well as axes of high magnetic anomalies may also be shown.

\section{Conclusions}

The advent of plate tectonic theory produced a revolution in the earth sciences (Wilson, 1968) so profound that all aspects of the science of geology required thorough re-evaluation in light of the new theory. Tectonic mapping is one of the more direct applications, but few such maps have been published to date. This may be partly due to rapid evolution of plate tectonic theory; however, in the two decades since its advent, the basic tenets have become more precisely defined. A new generation of tectonic maps based on plate tectonic theory should be prepared. As the geological properties of tectonic elements become better defined, so tectonic mapping will become more objective.



ABOUT THE AUTHOR:

Dr. J. Duncan Keppie is Chief Project Geologist with the Nova Scotia Department of Mines and Energy, Canada, where he has worked since 1974. His area of primary research interest is tectonics, especially in the Appalachians.

\section{References}

Argand, E., 1924, La tectonique de L'Asie: Congirs Ciologique internationale Comptes Rendus de la XIII" session,

Bates, R.L. and Jackson, J.A., (eds.), 1980, Glossary of GeoAm, Geol. inst., Falls Church, Virginia, p. 749.

Burke, K. and Dewey, J.F., 1973, An outline of Precambrian plate developenent: In: Tarling, D.H. and Runcorn, S.K. (eds.), Implications of continental drift to the earth sci-

Burke, K. Dewey, J.F, and Kidd, w.S.F., 1976, Dominance of Burke, Kant mevernents arc and microcontinental collisions during the later permobile regime: proceedings, In: Windley, B.F. (ed.), The Early History of the Eartht John Wiley

Burke, K. and whiteman, A.J., 1973, Uplift, rifting and the break-up of Africa: In: Tarling. D.H. and Runcorn, S.K. (eds.), Implications of continental drift to the earth sci-

Cebull, S.E., 1973, Concept of orogeny: Geol., I, no. 3, p Cebull, S.E. Chappell, B.N. and white, A.J.R., 1974, Two contrasting

Chekunov, A.V., 1967, Mechanism responsible for structure of the aulacogen type (taking the Dnieper-Donets Basin as

Coney, P.J., 1970, The geotectonic cycle and the new global

Dewey, J.F., 1969, Continental margins: a model for the conversion of Atlantic type to Ande
Plan. Sc. Let., v. 6, no. 3, p. 189.197. Dewey, J.F. and Horsfield, B., 1970, Plate tectonics, orogeny

Dickinson, W.R., 1977, Tectono-stratigraphic evolution of subduction - controlled sedimentary assemblages: In: Tal-
wani, M. and Pitman $\mathrm{ml}$, w.C. (eds.), Island arcs and deep sea trenches and back-arc basins: Amer. Geophy. Union, Washington, D.C., p. 33-40.

Douglas, R.J.W., 1973, Tectonics, Scale 1:15 000 000: In Nat. Atlas of Can., Dept. of Energy, Mines \& Res., Ottawa, Canada, p. 29-30. Hamilton, W., 1978, Tectonic map of the Indonesian region:
Scale i:s 000000 , Misc. Geol. Invest. Maps, U.S. Geol.

Geol. Invest. Maps, U.s. Geol. Hamilton, w., 1979, Tectonics of the Indonesian Region, U.S. Geol. Survey, Pro1. Paper 1078, Washington, D.C., map, p.

Holfman, P.F., 1980, Wopmay Orogen: a Wilson cycle of Early Proterozoic age in the northwest of the Canadian Shield, D.w. Strangway (ed.), The Continental Crust and its p. 523-552.

Illies, 3.H. 1969, An intercontinental belt of the world ritt system: Tectonophysics, v, 8, no. 1, p. $5-29$. Keen, C.E., 1979, Thermal history and subsidence of rifted tian and Labrador shelves: Can. Jour. of Earth Sc., v. 16, no. 3, Part 1, p. 505-522. Keppie, J.D., 1979, Geological Map of the Province of Nova
Scotia, Scale 1: 500000 : Dept. of Mines \& Energy, Halifax, Nova Scotia, Canada.

\footnotetext{
Keppie, J.D., in press, Tectonic of the Province of Nova
Scotias Scale I: 550000 . Nova Scotia Dept. of Mines and Energy, Halifax, Nova Scotia, Canada.

Kerr, R.A., 1978, Precambrian tectonicst is the present the
hey to the past? Science, v, 199, P. 282-285, 330 . King, P.B., 1969, The Tectonics of North America - A Discussion to accompany the Tectonic Map of North Amer. ica: Scale 1:5000 000, U.S. Ceol. Survey, Prof. Paper 628, Washington, D.C., p. 99.

Rona, P.A., 1973, Relations between rates of sediment accumulation on continental shelves, sea-floor spreading, and eustacy inferred from central North Atlantic: Geol. Soc.

Scheibner, E., 1972, Tectonic concepts and tectonic mapping: Records of the Geol. Surv, of N.S.W., Sydney, Australia, v.

Scheibner, E., 1974, The Tectonic Map of New South wales: Scale 1:1 000000 , 4 sheets, Geol. Surv. of N.S.W., Sydney,

scheibner, E., 1976, Explanatory notes on the Tectonic Map of New South Walest Scale
N.S.W., Sydney, Australia, p. 283. Schieferdecker, A.A.G., 1959, (ed.), Geological nomenclature:
English, Dutch, French, German: Royal Geol. \& Min. Soc. English, Dutch, Fren
of the Neth., p. 523 .

Wilson, J.T., 1968, Static or mobile earths the current no. 5, p. 309-320.

Williams, H., 1978, Tectonic Lithofacies Map of the Appalachian Orogen, Scale 1 il 000000 : Mertorial Univ. of
Nfld., St. John', NIld., Map No, 1, 2 sheets.
} 